\title{
Characterization of the postnatal early stimulation from a community context of family health
}

\begin{abstract}
Background: To improve the postnatal early stimulation from the Cuban community context of family health is a reality linked with the medical sciences.

Objective: To characterize the postnatal early stimulation from a community context of family health. This process embraced the period of June 2017 to May 2018. The qualitative methodology was used, with a descriptive and traverse study. The universe the 20 families of studies, selected in an intentional way. Methods: Observation and interview and the techniques were: test of family operation.
\end{abstract}

Results: it was evidence that toxic styles of life exist, nutritional deficit with underweight in the infant, with hypoxias when being born that they impact in the brain and in the infantile stimulation starting from nixes in the family.

Conclusion: The families present difficulty in the life with the different psychological adaptations and they don't improve the infantile stimulation in the brain the family context.

Keywords: psychological adaptations, postnatal early stimulation, family, infantile neurology, families, family health, social group, global action, biological development, investigative work, analytic synthetic, family health, clinical history
Volume 2 Issue 5 - 2018

Jesús Cuéllar Álvarez

Department of Ceasing Tobacco, University Central Marta Abreu de las Villas, Cuba

Correspondence: Jesús Cuéllar Álvarez, Department of Ceasing Tobacco, University Central Marta Abreu de las Villas, Cuba,Tel+53 54785830,Email jesusca@infomed.sld.cu

Received: August 08, 2018| Published: September 04, 2018

\section{Introduction}

The family is the most important social group in any society, it is the place where the formation of the personality begins and where the affections are committed with the interactions among their members. ${ }^{1}$ The early stimulation is conceptualized as all process of acquisition of new adaptations in the period of development with an address, sense, organization and elements of improvement before its application. ${ }^{2}$ The stimulation postnatal is based on the global action that is applied the children in an early way, fundamental objective in that the investigative work is centered. ${ }^{2}$ The Rehabilitation is centered in a process where they combine measures doctors, psychological, social and educational that help individuals with the objectives of reaching the highest operation levels and integration linked to diverse contexts or factors interrelated. ${ }^{3}$ The neuro development is a science that keeps narrow relationship with the neuropsychology with the result that the same one allows a process of maturity in the man's biological development and its relationship with the synthesis neuronal giving place to the participation of the Central Nervous System. In such a sense thinks about the following scientific problem: How characteristic it presents the postnatal early stimulation from a context of community family health? The General Objective that thinks about is to characterize the postnatal early stimulation from a context of community family health. ${ }^{4}$

\section{Methods}

The families was carried out a descriptive study, traverse with infantile belonging to the policlinic "José Ramón León Acosta" of the municipality Santa Clara, Cuba in the understood period of June 2017 to May 2018, with the objective to characterize the postnatal early stimulation from a community context of family health. It was study object a universe constituted by 20 families of studies, selected in an intentional way. Methods of the theoretical level: Analytic synthetic: It facilitated the interpretation of the texts and to establish the corresponding generalizations. Inductive-deductive: facilitated to go of the peculiar to the general thing in each one of the analyses carried out in the theoretical study. Generalization: It allowed the establishment of the regularities that showed in the carried out study. ${ }^{5}$

\section{Empiric level}

Revision of family records: It constitutes a legal document, doctor and official zed of great personal and acquisitive value, to be registered all the relative one prior to the clinical history of the family, having a truthful character, if one kept in mind with the objective of more thoroughly know to the same ones and to value their physical and mental state previously, gathering and obtaining a more reliable and richer information for the investigation.

Test of family operation: It is applied with the objective of measuring the level and incidence of some determinant of the health in the context of the family, talkative affective relationships, communication styles.

\section{Inclusion approaches}

I. Families that are low treatment of postnatal early stimulation.

II. That they resided in the area of chosen health. ${ }^{7}$

\section{Exclusion approaches}

I. Families that emigrate of their residence place during the study. 


\section{Exit approaches}

I. Families that abandon the investigation voluntarily.

\section{Collection of the information}

It was used the triangulation like fundamental methodology of analysis with the purpose of to contrast and to establish a crossed control of the data obtained by the different roads of information.

\section{Statistical analysis}

The information was stored in a file of data in SPSS version 21.0 and it is presented in statistical chart; for the description it was calculated with the method statistic of Fisher. One worked with significance levels to $5 \%$ Fisher. $^{8}$

\section{Results}

As for the family operation $52,7 \%$ of the family nuclei obtained the qualification dysfunctional followed by the severely dysfunctional with $19,4 \%$. The educational method with observed more frequency was the inconsistence in $19(52,7 \%)$ of the family nuclei, while the permissiveness and rigidity were presented in $10(27,7 \%)$ and 5 $(13,8 \%)$ of them respectively. The evidences as it is shown in the Table1 they are clear as for that the family setbacks contribute to limit the infantile postnatal early stimulation due to the inadequate communication that their members present and that they have their base in the inadequate attitudes adopted by the family. As a result of the first stage, where the behaviors of low risk were diagnosed in the majority representation of the 15 infants accompanied by their families that corresponds to the study sample, and manifested that the infants are usually subject to nexus environmental psycho emotional being object of psychological alterations in the infants as the anxiety taken place in a perceived intermittent or persistent cry it corresponds to a nutritional deficit for the feeding lack in the mother that generates underweight when being born as high risk in the infants as well as endocrine and metabolic dysfunctions for the hypoglycemia presence, where they are also those mothers and smoking parents that adopt an inadequate lifestyle, giving place to an infantile passive smoker inside the of family health. These results coincide with the investigations carried out in this respect, where, certainly the risks factors spread to be expressed in a family dysfunctional swim a nursling and infant that their cerebral maturation will depend depending from the conditions associated to the family like special group of development.

It was verified through the family records that should improve the situation of the family health, stimulating through integrated actions, dynamic and systematic the own infantile development for the members of the group special relative in a healthy way in their internal operation. It was corroborated starting from the record of family health that while a nutritional deficit exists with relationship to the mother and the infant, a first floor weight will be evidenced when being born, that which will rebound in the infantile development and will bring metabolic and even endocrine dysfunctions that can be linked to depressions and anxieties manifested in a frequent cry as answer to a demand psychosocial in the infant inside the family environment. You could verify that for the results offered by the technique of family operation that was evidenced families with inadequate toxic life styles under the presence of environmental that block the appropriate development toward a postnatal early stimulation.

Table I Method educational employee and family operation

\begin{tabular}{|c|c|c|c|c|c|c|c|c|c|c|}
\hline \multirow{3}{*}{ Family operation } & \multicolumn{4}{|c|}{ Method educational } & \multirow{2}{*}{\multicolumn{2}{|c|}{ Rigidity }} & \multirow{2}{*}{\multicolumn{2}{|c|}{ Protection }} & \multirow[b]{2}{*}{ Tot } & \\
\hline & \multicolumn{2}{|c|}{ Inconsistente } & \multicolumn{2}{|c|}{ Permissiveness } & & & & & & \\
\hline & No & $\%$ & No & $\%$ & No & $\%$ & No & $\%$ & No & $\%$ \\
\hline Functional & 1 & 2,77 & 0 & 0 & 0 & 0 & 2 & 5,55 & 3 & 8,3 \\
\hline Moderately functional & 0 & 0 & 2 & 5,55 & 5 & 13,8 & 0 & 0 & 7 & 19,4 \\
\hline Dysfunctional & $\mathrm{II}$ & 30,5 & 8 & 22,2 & 0 & 0 & 0 & 0 & 19 & 52,7 \\
\hline Severely dysfunctional & 7 & 19,4 & 0 & 0 & 0 & 0 & 0 & 0 & 7 & 19,4 \\
\hline Total & 19 & 52,7 & 10 & 27,7 & 5 & 13,8 & 2 & 5,55 & 36 & 100 \\
\hline
\end{tabular}

Statistic of Fisher $=31,596 p=0,000$

Source: Family clinical histories

\section{Discussion}

The life style continues being a determinant of the health focused in the diverse behaviors that the individuals assume in different contexts of the daily life. ${ }^{9}$ The social representation of the families in the area of the family health consists on the subjective construction that each fellow carries out in function of to improve or to worsen his quality of life. ${ }^{10}$ The current family health will depend on the concept that assimilates the family special group, knowing that for health understands each other the well-being spiritual and cultural bio psychosocial, not the absence of illnesses. ${ }^{11}$ The Rehabilitation family psychosocial as process should be flexible individualized, although certainly it is made in group, being creative and with a stimulus to the motivations in the infants, with a purpose educative that offers in long periods that it is of 2 years as minimum. ${ }^{12,13}$ In such a sense the members of the family should contribute with appropriate attitudes to the improvement of an effective communication that allows a dynamic and systematic development for the infantile postnatal early stimulation facilitating a cerebral maturation in the infant. They offered favorable valuations so much from the evaluation of the content of the psychological adaptations, for what was considered that it is adjusted to the necessities identified in the initial stage of the investigation and it can constitute an alternative to improve the integral family health in the infant. This way it is required in a dynamic and systematic way of psychological adaptation, guided to produce answers cognitive and behavioral of early stimulus, focused in the damaged functions as in those conserved, without obviating the paper of support of the family. ${ }^{14}$

\section{Conclusion}

While there is lack of abilities cognitive and behavioral on the part 
of the family, risks that affect the infantile postnatal early stimulation in the development, will prevail and that according to the lifestyle of the members of the family the appropriate and inadequate states will be evidenced that will influence in the postnatal early stimulation that eat social representation has the same one as a special group. By way of conclusion according to like the internal and external conditions are developed starting from the interaction with the diverse subjective configurations from the family context, it will be this way the evolution of the postnatal infantile early stimulation, what to carry out this investigation work opened a new door to the knowledge, attributing to the family an infrastructure cognitive and behavioral able to contribute to the improvement of the postnatal early stimulation and to prevent risks that affect the infantile development from their own special group, and should improve for the family the affective relationships of communication for the achievement adapted in the infantile postnatal early stimulation.

\section{Acknowledgements}

None.

\section{Conflict of interest}

The author declares no conflict of interest.

\section{References}

1. Arés P. Psicología de la familia. Una aproximación a su estudio. La Habana: Félix Varela; 2002.

2. Regüefeiros Prego L. Neurodesarrollo y discapacidad infantil. La Habana: Editorial Científico Técnico; 2012.

3. Cabana Pérez D, Guridi González MZ, Franco Pedraza V. Caracterización biopsicosocial de familias con atención postnatal solos en el área de salud de Calabazar, Boyeros. Rev Hospital Psiquiátrico de La Habana. 2014;11(2):6.

4. Sampieri R, Fernández C, y Baptista P. Metodología de la investigación. (Sexta Edición). México: Graw- ill/Interamericana, S.A. de C.V, 2015.

5. Núñez de Villavicencio. Psicología y Salud. Ciudad de la Habana: Editorial Ciencias Médicas; 2006.

6. Colectivo de Autores. Violencia de género en las familias. La Habana: Editora Acuario; 2012.

7. Rodríguez Sánchez J. Mi psicólogo soy yo. Editorial Científico-Técnico, La Habana; 2002.

8. González Llanesa F. Instrumentos de evaluación psicológica La Habana: Ciencias Médicas; 2010.

9. López Ramo D, Alonso Álvarez A, García Penedo H. Estilos de vida en familia. Rev Hosp Psiquiátrico de la Habana. 2013;10(1):9.

10. Mayo Sánchez JM, Fabelo Roche JR, Iglesias Moré S, Puente Fabelo M. Representación social de los pacientes en médicos de familia. Rev Hosp Psiquiátrico de la Habana. 2013;10(3):10.

11. Organización Mundial de la Salud. Definición de Salud según la OMS. Informe del Comité de Expertos de la OMS. Ginebra: OMS; (Serie de Informes Técnicos: 650); 1980.

12. Organización Mundial de la Salud. Resolución 58.26 de la 58 Asamblea Mundial de la Salud titulada Problemas de Salud Pública y la rehabilitación. Ginebra Mayo; 2005.

13. Pérez Díaz R, Martín Carbonell M, Riquelme Marín A. Rehabilitación. Rev Hosp Psiquiátrico de la Habana. 2013;10(1):8.

14. Sandoval Ferrer JE, Díaz Nóbregas JA, Alonso Álvarez A, Fraga Guerra E. Rehabilitación y funciones en la familia. Rev Hosp Psiquiátrico de la Habana. 2013;10(3):9. 